\title{
Three new species of Leptohyphes Eaton (Ephemeroptera: Leptohyphidae) from Colombia
}

\author{
Carlos Molineri', María del Carmen Zúñiga ${ }^{2,3}$, Blanca C. Ramos², Lina P. Giraldo³ \& William Cardona ${ }^{4,2}$ \\ 1. Instituto de Biodiversidad Neotropical, CONICET (National Council of Scientific Research), Universidad Nacional de Tucumán, Facultad de Ciencias Naturales y \\ Instituto M. Lillo, M. Lillo 205 (4000), Tucumán, Argentina. (carlosmolineri@gmail.com) \\ 2. Grupo de Investigaciones Entomológicas, Departamento de Biología, Universidad del Valle, Santiago de Cali, Colombia. \\ (maczuniga@gmail.com; blancera@gmail.com) \\ 3. Centro para la Investigación en Sistemas Sostenibles de Producción Agropecuaria - CIPAV, Santiago de Cali, Colombia. (lina@fun.cipav.org.co) \\ 4.Wildlife Conservation Society (WCS) - Programa Colombia, Santiago de Cali, Colombia. (williamcardona@gmail.com)
}

ABSTRACT. Three new species of Leptohyphes Eaton, 1882 (Ephemerotera: Leptohyphidae) are described, diagnosed and illustrated from nymphs collected in Colombia. Geographical ranges and ecological notes relating important environmental variables are given for each species. Leptohyphes andina sp. nov. is characterized by: forefemur length / maximum width 1.8-1.9, fore and hind margin of middle and hind femora with strong spine-like setae on elevated sockets, femoral surface covered by small pale spots, apex of femora with anterior margin roundly projected distally, tarsal claw only with 3-4 marginal denticles, pronotum with triangular lateral projection, hind wing pads present in female, gill formula 3/5/5/5/2, gill V with ventral extension on dorsal lamella. Leptohyphes quimbaya sp. nov. presents the following characters: body covered by hair-like setae, with paired short and blunt tubercles on abdominal terga V-IX, femora wide (forefemur length/ maximum width 1.6), fore and hind margin of femora with tiny spine-like setae, tarsal claws with 2-3 marginal denticles, pronotum with triangular (but apically blunt) lateral projection, hind wing pads present in females, gill formula 3/7/7/5/2, gill V without ventral extension on dorsal lamella. Leptohyphes calarca sp. nov. is distinguished by: pilose body, slender femora (forefemur length / maximum width 2.3), foremargin of middle and hind femora without setae, tarsal claws with 5 marginal denticles and 1 submarginal subapical denticle, pronotum strongly projected laterally, fore wingbuds blackish, hind wing pads present in females, gill formula 3/4/4/3/1, gill V with ventral extension on dorsal lamella.

KEYWORDS. Aquatic insects, biodiversity, mayflies, taxonomy, Leptohyphes, Colombia.

The genus Leptohyphes Eaton, 1882 (Ephemeroptera: Leptohyphidae) is represented by 42 species (HofmanN et al., 1999; Molineri, 2003, 2010; Domínguez et al., 2006; BAUMGARDNER \& MCCAFFERTY, 2010; NASCIMENTO et al., 2014), distributed in South America, Central America, including the Antilles, and North America. Of these, 25 are reported from South America, and are distributed mainly along the Andes from Northern Argentina to Colombia (MoLINERI, 2010), but they are represented also in the Atlantic forest from Brazil (NAScimenTo et al., 2014). The nymphs of the genus are frequently found in Andean rivers and streams, constituting an important portion of the benthic community (ZúÑiga et al., 2004; DomíngueZ et al., 2006; Molineri, 2010; ZúÑIGA et al., 2013). They are collector gatherers of fine particulate organic matter (ToMANOva et al., 2006; CharÁ-SERna et al., 2010, 2012; REYNAGA \& Dos SANTOS, 2013; GuZmÁN-Soto \& TAMARIZ-TuRIZO, 2014); nymphs inhabit clean to scarcely polluted ecosystems (ZúÑIGA DE CARDozo et al., 1997; DomíngueZ et al., 2006; ZÚÑIGA \& CARdona, 2009).

Leptohyphes in Colombia is abundant showing a wide distribution and altitudinal range. Six species are recorded, mainly in the Andean range of the country: L. albipennis Molineri \& Zúñiga, 2006, L. ecuador Mayo, 1968 (Dias et al., 2011), Leptohyphes jodiannae Allen, 1967 (ZúÑIGA et al., 2014), Leptohyphes maculatus Allen, 1967 (MoLINERI, 2010; ZúÑIGA et al., 2014) and L. nigripennis Molineri \& Zúñiga, 2006 (Molineri, 2010). All these species are known from both stages, except $L$. jodiannae (only known from nymphs). Two of them are endemic to Colombia ( $L$. albipennis and L. coconuco), while the others are recorded also from other countries of the region: Bolivia (L. nigripennis and L. maculatus), Ecuador (L. ecuador and L. maculatus) and PerU (L. jodiannae and L. maculatus).

The aim of the present paper is to describe and illustrate the nymphal stage of three new species collected in the Andean region of Colombia.

\section{MATERIAL AND METHODS}

Nymphs were collected with different aquatic nets (surber sampler, kicknet, D-frame net, hand nets) and fixed and preserved in 96\% ethanol. Mouthparts and legs were dissected under 10x magnification and mounted on 
microscope slides, using Euparal ${ }^{\circledR}$ or Canada Balsam. The character "gill formula" was used in descriptions of species in the form of a numeric series (e.g., 3/11/9/9/6), where the first number represents the number of gill lamellae present in each gill on the first abdominal segment, second number represents the number of lamellae present in each gill of the second abdominal segment and so on. The tarsal claw denticulation is also represented as a formula (e.g., 2-3 + 0 ) indicating first the number of marginal denticles on the basal half of the claw (in the example varying from 2 to 3) plus the number of apical submarginal denticles (in this case, absent), following MoLINERI (2003). The presence of hind wings (or wing pads) is only mentioned in females because they are always present in the males of the genus (Molineri, 2003).

Photographs were taken using a stereomicroscope with a digital camera. Line drawings were done using a camera lucida attached to a microscope. Maps were made with Geographic Coordinate System: GCS Bogotá, Datum: D Bogotá and the software ESRI® ArcMap 10.0 licence ArcInfo.

The material examined is deposited in the following institutions: Museo de la Universidad del Valle (MUSENUV), Cali, Colombia, and Instituto de Biodiversidad Neotropical (IBN), Tucumán, Argentina.

\section{RESULTS}

\section{Leptohyphes andina Molineri, Zúñiga \& Ramos, sp. nov.}

(Figs 1, 4-5, 10-15)

\section{LSIDurn:lsid:zoobank.org:act:3FDC332A-ADAD-4E77- 9223-9A0378A398E4}

Type material. Holotype $q$ mature nymph from COLOMBIA, Risaralda, La Celia, La Argelia farm, creek La Argelia, 0500’31.2”N, 7557’18.3”W, 1416 m, 19.II.2011, W. Cardona col. (MUSENUV). Paratypes: $12 q$ and $2{ }^{\wedge}$ nymphs, same data as holotype (9 nymphs in MUSENUV, 6 in IBN).

Additional material. Five mature nymphs $\left(4 ㅇ, 1{ }^{\Uparrow}\right)$ and 19 immature nymph from COLOMBIA, Valle del Cauca, Ulloa, La Divisa-La Suerte farm, La Divisa-La Suerte creek, La Vieja river basin, 04²1'23”N, 7543’49”W, 1480 m, microhabitat: stream bed stone, 12.XI.2003, J. Chará, L. P. Giraldo, D. Hincapié, G. Pedraza cols. (MUSENUV); 3 mature nymphs $(2 \circ, 1 \hat{\jmath}), 2 \bigcirc$ immature nymphs, the same information except microhabitat: silt (MUSENUV); 10 mature nymph, the same information except La Azulita farm, La Azulita creek, La Vieja river basin, 0441'45”N, 7543'07'W, 1430 m, microhabitat: sandy, 11.XI.2003 (MUSENUV); 10 mature nymph, the same information except microhabitat: stream bed stone (MUSENUV); 4 mature nymphs $\left(3 \circ, 1 \jmath^{\Uparrow}\right), 3$ immature nymphs $(1 q, 2 \AA)$, the same information except El Recreo II farm, El Recreo
II creek, La Vieja river basin, 0441'46”N, 7544’04”W, 1418 m, microhabitat: silt, 12.XI.2003 (MUSENUV); 3 mature nymphs $(1 \uparrow, 2 \hat{\jmath})$, the same information except $\mathrm{La}$ Cabaña II farm, La Cabaña II creek, La Vieja river basin, 0441'36”'N, 7544'09'”, 1430 m, microhabitat: stream bed stone 12.XI.2003 (MUSENUV); 10 mature nymphs ( 8 +, $\left.2 \bigcirc^{\Uparrow}\right)$, Valle del Cauca, Cartago, El Porvenir II farm, El Porvenir II creek, La Vieja river basin, 04³9’17’N, 7553’09”W, 1386 m, microhabitat: stream bed stone, 2.XII.2003, J. Chará, L. P. Giraldo, D. Hincapié, G. Pedraza cols. (MUSENUV); 5 mature nymphs $(3 \bigcirc, 2 \hat{\jmath})$, the same information except Canelones-Miravalle farm, Canelones-Miravalle creek, La Vieja river basin, 04³9’15”N, 7553'07’W, 1366 m, microhabitat: stream bed stone, 2.XII.2003 (MUSENUV); $2 \hat{\jmath}$ mature nymphs, the same information except TesaliaDos Quebradas farm, Tesalia-Dos Quebradas creek, La Vieja river basin, 04³9'09”'N, 7555’34”'W, 1378 m, microhabitat: aquatic macrophytes, 2.XII.2003 (MUSENUV); 10 mature nymph, Valle del Cauca, Alcalá, Pasatiempo farm, Pasatiempo creek, La Vieja river basin, 0440’39’N, 7544’16”'W, 1360 m, microhabitat: stream bed stone, 10.XII.2010, J. Chará, L. P. Giraldo, D. Hincapié, G. Pedraza cols. (MUSENUV); 4 mature nyphs $(3 q, 1 \precsim)$, the same information except La Frontera farm, La Frontera creek, La Vieja river basin, 0440’43”N, 7543’38”W, 1408 m, microhabitat: leaf packs, 10.XII.2003 (MUSENUV); 8 mature nymphs (5ㅇ, $3 \precsim$ ), Risaralda, Santuario, La Gaviota Farm, La Gaviota creek, Mapa river basin, 0502’39.76”N, 7559’40.4”W, 638 m, microhabitat: stream bed stone, 12.II.2011, W. Cardona col. (MUSENUV); 19 mature nymphs $\left(13+, 6 \bigcirc^{\Uparrow}\right)$, Risaralda, La Celia, La Esmeralda farm, San Camilo creek, 0502'8.5”N, 7559'46.7'W, 1648 m, microhabitat: stream bed stone, 11.II.2011, W. Cardona col. (MUSENUV); 1 mature nymph, the same information except La Pradera farm, La Reina creek, Monos river basin, 0457'52.7'N, 7600'7’'W, 1480 m, microhabitat: stream bed stone, 15.II.2011 (MUSENUV); 1 mature nymph, the same information except La Reina farm, La Reina creek, Monos river basin, 0457’44.5”N, 7600'27.2”W, $1585 \mathrm{~m}$, microhabitat: stream bed stone 14.II.2011 (MUSENUV); 2 immature nymphs ( 1 ㅇ, $1 \precsim$ ), the same information except Villa Lux farm, Villa Lux creek, Totui river basin, $05^{\circ} 00^{\prime} 40.6^{\prime}$ N, 7557'42.8”'W, $1641 \mathrm{~m}$, microhabitat: stream bed stone 18.II.2011 (MUSENUV); 4 mature nymphs $(+9), 5$ immature nymphs $\left(3 \circ, 2{ }^{\Uparrow}\right)$, the same information except La Florida farm, La Florida creek, río Monos basin, 0458'6”N, 7600’7.6”W, 1375 m, microhabitat: stream bed stone 16.II.2011 (MUSENUV); 9 mature nymphs $(6 \circ, 3 \overbrace{}^{\Uparrow}), 4$ immature nymphs $(1+, 3 \overbrace{}^{\Uparrow})$, Risaralda, Pereira, Santa Cecilia creek, Otún river basin, 0453'26”'N, 7548'34’W, 950 m, microhabitat: leaf packspools, 12.III.2008, J. Chará, L. P. Giraldo, A. M. Chará-Serna, A. Giraldo cols. (MUSENUV); $8 \AA$ immature nymphs, 10 mature nymphs, the same information except microhabitat: leaf packs-riffles (MUSENUV). 16 mature nymphs (11, , $5 \hat{\jmath}), 4$ immature nymphs $(1 \propto, 3 \hat{\jmath})$, the same information except Cristales creek, Otún river basin, 0452’43”N, 7549’28’W, 1057 m, microhabitat: leaf packs-riffles, 


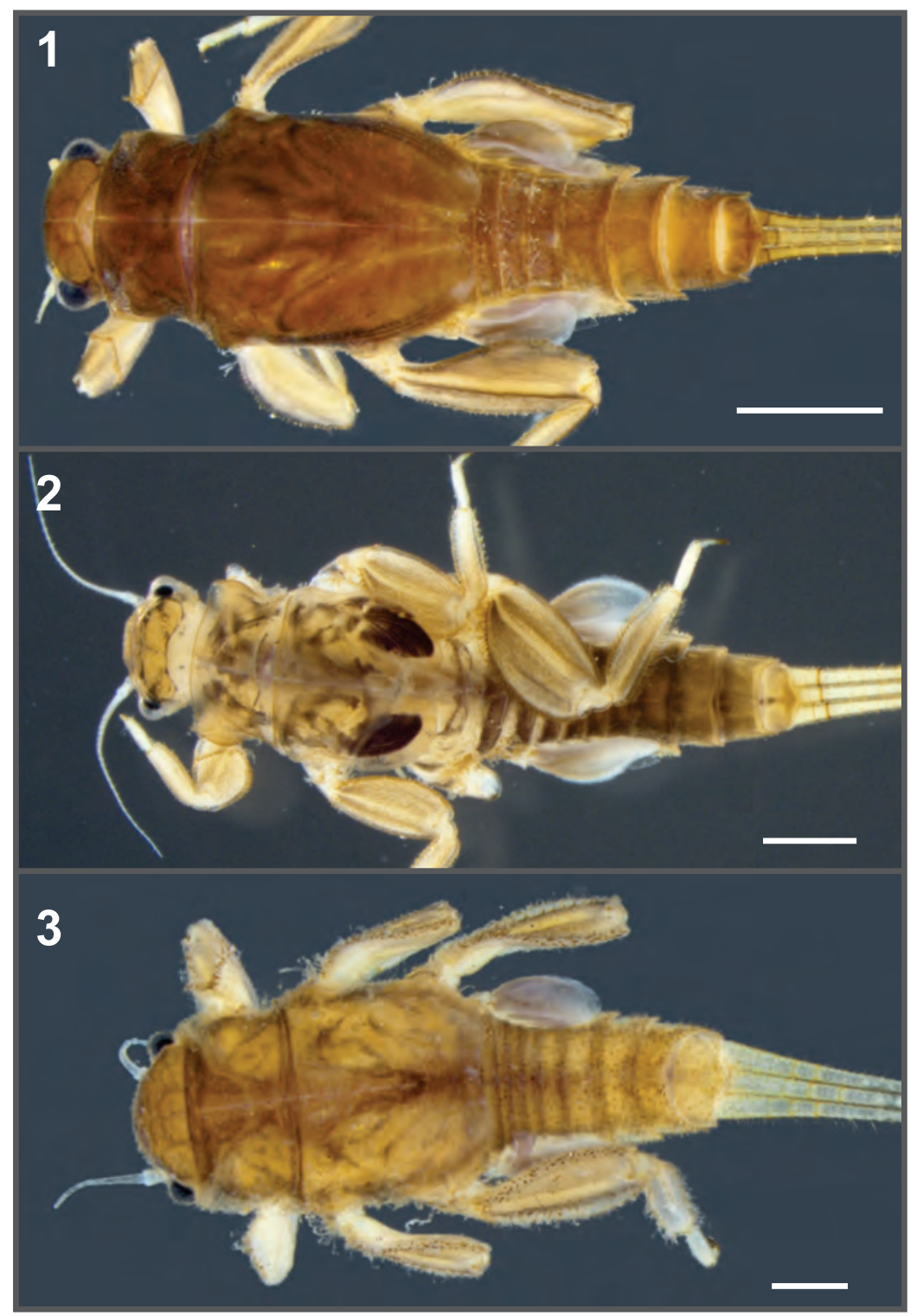

Figs 1-3. General habitus of nymph, dorsal: 1, Leptohyphes andina sp. nov.; 2, L. calarca sp. nov.; 3, L. quimbaya sp. nov. Scale bars = 1 mm.

11.II.2008 (MUSENUV); 19 immature nymph, the same information except La Pedregosa creek, Otún river basin, 0453'22.9”'N, 7549'16.4”'W, 1024 m, microhabitat: leaf pack-pools, 11.II.2008 (MUSENUV); $10^{\Uparrow}$ mature nymph, 5 immature nymphs $\left(4 \circ, 1{ }^{\pi}\right)$ the same information except microhabitat: leaf pack-riffles (MUSENUV); $10^{\Uparrow}$ mature

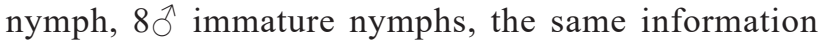
except Santa Cecilia creek, Otún river basin, 0453’26”N, 7548’34”W, $950 \mathrm{~m}$, microhabitat: leaf pack-riffles, 12.III.2008 (MUSENUV); 6 ? mature nymphs, $4{ }^{\lambda}$ immature nymphs, Quindío, Quimbaya, El Ocaso farm, El Ocaso creek, La Vieja river basin, 03²4'27’'N, 76³1'7.2”W, 1526 m, microhabitat: stone, 3.XII.2002, J. Chará, L. P. Giraldo, G. Pedraza cols. (MUSENUV); 6 matures nymphs (4ㅇ, 2§), $1 \delta^{\Uparrow}$ immature nymph, Quindío, La Tebaida, Putumayo farm, Putumayo creek, La Vieja river basin, $04^{\circ} 27^{\prime} 8^{\prime}$ 'N, 7549’6.8”W, 1100 m, microhabitat: aquatic macrophytes,
28.II.2003, J. Chará, L. P. Giraldo, G. Pedraza, D. Hincapie cols. (MUSENUV).

Diagnosis. 1) tubercles on body absent (Figs 1, 4-5); 2) forefemur length / maximum width 1.8-1.9 (Fig. 14); 3) fore and hind margin of middle and hind femora with strong spine-like setae on elevated sockets (Fig. 13); 4) femoral surface covered by small pale spots; 5) apex of middle and hind femora with inner apical corner more distally projected than the outer corner (arrow in Fig. 13); 6) tarsal claws: 3-4+0 (Fig. 15); 7) pronotum with triangular lateral projection (arrow in Figs 4, 11-12); 8) hind wing pads present in female; 9) gill formula $3 / 5 / 5 / 5 / 2$, gill $V$ with ventral extension on dorsal lamella.

Description. Mature nymph. Length of female (mm): body, 4.8-5.4; hind femur, 1.4-1.5; caudal filaments, 5.5-5.6. Length of male (mm): body, 3.3-3.5; hind femur, 1.0-1.1; caudal filaments, 3.2-3.6. General coloration light brown. 


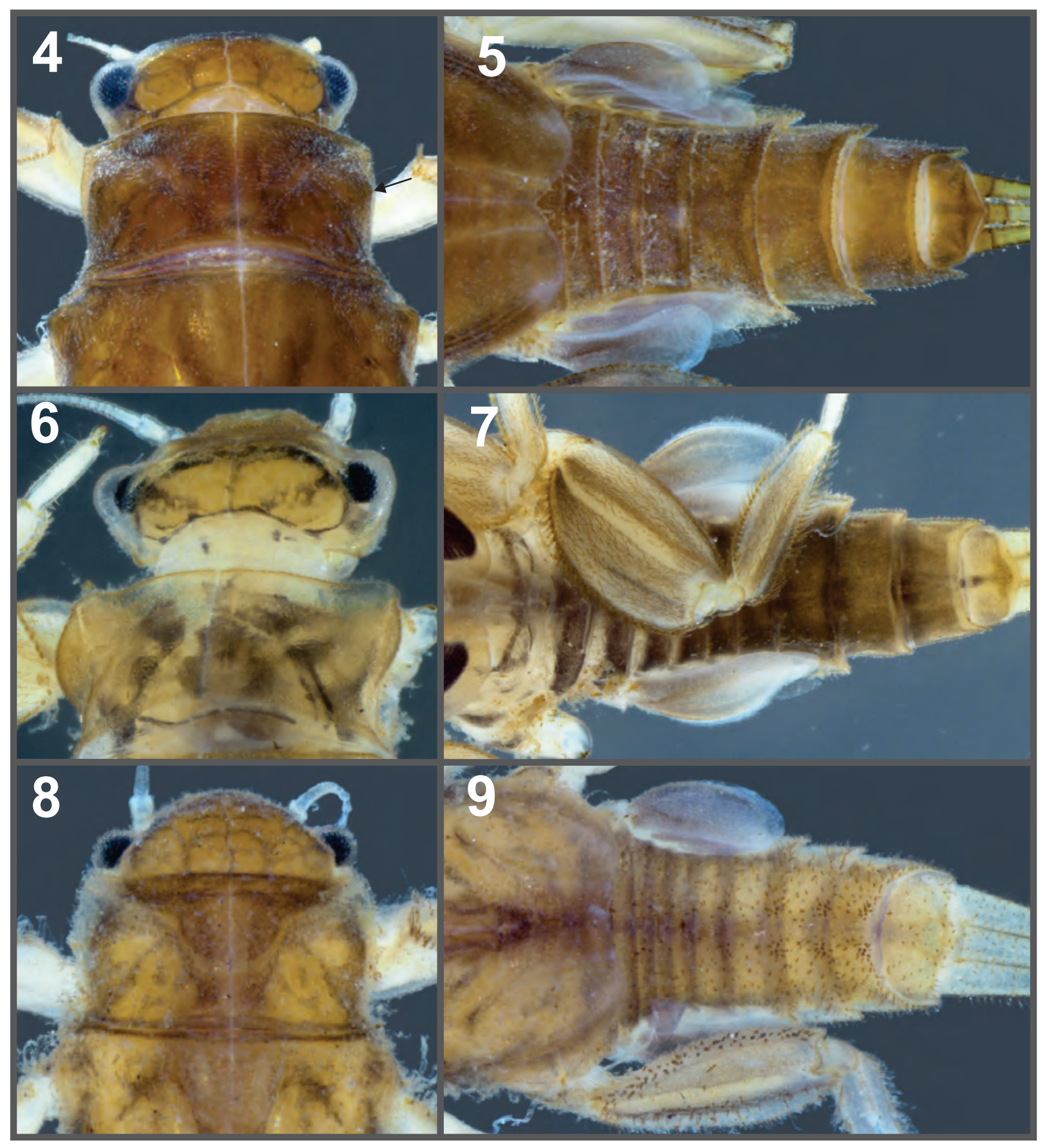

Figs 4-9. Head/pronotum, and abdomen, dorsal: 4-5, Leptohyphes andina sp. nov.; 6-7, L. calarca sp. nov.; 8-9, L. quimbaya sp. nov.

Head color pattern: blackish transverse band between compound eyes (extending from posterolateral margins of eyes, then going anteriorly to transverse epicranial suture until the other compound eye, Figs 1, 4, 10), occiput finely shaded with gray forming a net-like pattern. Antennae yellowish white. Thorax (Figs 1, 4, 11, 12): nota brownish with irregular gray and black markings, costal margin of wingbuds blackish (Fig. 1); ventrally paler. Pronotum subrectangular with subtriangular lateral projection (Figs 4, 11, 12). Mesonotum with subtriangular blunt anterolateral projection (Figs 4,
11-12). Hind wing pad present in female. Legs yellowish slightly shaded gray dorsally except mediolongitunidal pale line on femora. Ratios: length fore femur/hind femur (x 100) $=64-65 \%$. Foreleg (Fig. 14): femur ratio length/maximum width 1.8-1.9; transversal row at 0.6 from base to apex; foremargin with small spine-like setae, hind margin with spine-like setae distally to transversal row. Tibia subequal in length to femur with tiny spine-like setae along outer margin (Fig. 14). Tarsus $1 / 2$ the length of tibia with row of setae in inner margin; tarsal claw apically curved with four marginal 
denticles, without subapical submarginal denticle (Fig. 15). Middle and hind legs (Fig. 13) similar in form and setation, except middle leg smaller; apex of middle and hind femora with inner apical corner more distally projected than the outer corner (arrow in Fig. 13). Hind femur ratio length/maximum width 2.1-2.4; foremargin with double row of spatulate setae, hind margin with 36-42 spatulate setae, dorsal surface with 12-15 small setae along medial axis. Tibia subequal in length to femur, with dorsal ridge, inner and outer margins with long spatulate setae. Tarsus 0.3-0.4 the length of tibia, inner margin with setae, tarsal claw as in foreleg. Abdomen (Figs 1,5 ) brownish diffusely shaded with gray; terga III-VII with few spine-like setae on lateral areas; terga II-IX with a pair of blunt spine-like setae submedially (commonly broken off and lost); hind margin of all terga and lateral margins of VII-IX with small spine-like setae; segments III-VI forming lateral flanges; small posterolateral projections present on VI-IX. Gills: operculate gill gray, ventrally with strong and curved "basal spine" and two lamellae; other gills grayish to hyaline. Gill formula 3/5/5/5/2; gill V with small rounded extension on ventro-basal margin, gill VI with larger lamella ventrally projected. Caudal filaments with whorl of spines and setae at joinings.

Adults. Unknown.

Etymology. The specific epithet refers to the Andes. Distribution (Fig. 28). Colombian Andes (Central and Western Cordillera) in the departments of Quindio, Risaralda and North of Valle del Cauca, from 750 to 1648 masl.

Discussion. The unique combination of characters distinguishing $L$. andina from other species in the genus is listed in the diagnosis. Some of these characters are shared by other species, as follows: pronotum with triangular lateral projection (also present in L. quimbaya), femora with pale spots (present in L. liniti Wang et al., 1998, L. petersi Allen, 1967, L. murdocki Allen, 1967, L. alleni Brusca, 1971), femora with spine-like setae on fore and hind margins (also present in many species except those mentioned above for the pale spots). The femora (middle and hind) with inner apical corner more projected than the outer is a unique characteristic, not reported before in the genus.

Ecological notes. Nymphs were found mainly in small streams from the middle basin of La Vieja river (departments of Valle del Cauca and Quindío). The area is a human driven ecosystem with coffee and banana plantations, and cattle rising as the main activities. The marginal areas of the streams presented some kind of plant cover, mainly herbs, bushes, and bamboo (Guadua angustifolia Kunth, 1822) or relatively well-preserved secondary forests. These streams varied from 4 to $20 \mathrm{~cm}$ in depth, 46 to $606 \mathrm{~cm}$ in channel width, and 0.5 to $31 \mathrm{l} / \mathrm{s}$ of discharge. Bed substrate is formed by gravel $(11 \%)$, stones $(26.6 \%)$ and sand/slime $(62.8 \%)$. Mean water temperature was $21^{\circ} \mathrm{C}$ and did not present severe organic loads. Mean ICA-FSN quality index was 60.6 corresponding to good environmental quality (OTT, 1981). Other variables are: mean dissolved oxygen $(5.2 \mathrm{mg} / \mathrm{l})$, low biochemical oxygen demand (0.69 mg/l), and variable $\mathrm{pH}$ (5.8 to 8.4) indicating an acid-basic stable buffer system (CHARÁ et al., 2009).

\section{Leptohyphes calarca Molineri, Zúñiga \& Ramos sp. nov.}

(Figs 2, 6-7, 16-20)

\section{LSIDurn:Isid:zoobank.org:act:6A6C9D87-ED48-4339- 89C7-5F89667B15B3}

Type material. Holotype $\bigcirc$ mature nymph (parts on slide) from COLOMBIA, Quindío, Calarcá, Natural Reserve La Sonadora, No 1 creek, tributary of the La Sonadora creek, Verde river basin, $3076 \mathrm{~m}, 04^{\circ} 25^{\prime} 56.4^{\prime \prime} \mathrm{N}, 7^{\circ} 37^{\prime} 29.4^{\prime \prime} \mathrm{W}$, microhabitat: cobble and gravel mixture, 6.VIII.2010, A. Villarreal col. (MUSENUV). Paratypes: $2 q$ nymphs, the same information except microhabitat: sandy, 15.I.2010 (IBN); 1 을 nym, the same date except, No 2 creek, $3000 \mathrm{~m}$, 04²6'1.9”N, 75³7'30.1'W, microhabitat: cobble and gravel mixture 10.IX.2010 (IBN); 1 nymph, the same information except No 3 creek, tributary of the La Sonadora creek, Verde river basin, $2900 \mathrm{~m}, 04^{\circ} 25^{\prime} 37.3^{\prime \prime} \mathrm{N}, 7^{\circ} 36^{\prime} 40.3^{\prime \prime} \mathrm{W}$, microhabitat: cobble and gravel mixture, 8.X.2010 (MUSENUV); 19 mature nymph, the same data except, La Sonadora creek, 2800m, 04²6'37.2”N, 75³7’46.5”W, microhabitat: cobble and gravel mixture, 5.XII.2010 (MUSENUV); 3 + nymphs, the same information except, El Cedral creek, 2915 m, 04²5’27.6”N, 75³6’36.1”W, microhabitat: cobble and gravel mixture, 11.XI.2010 (MUSENUV).

Diagnosis. 1) large size, without tubercles on its pilose body (Figs 2, 6-7); 2) fore femur slender, length/ maximum width $=2.3$ (Fig. 18); 3) fore margin of middle and hind femora without spine-like setae (but with many small curved setae), hind margin with ca. 40 medium-sized spatulate setae, elevated sockets absent or vestigial (Fig. 16); 4) tarsal claws denticulation 5+1 (Fig. 17); 5) pronotum strongly projected laterally (Fig. 6); 6) fore wingbuds blackish (Fig. 2) (before folding in mature nymphs), hind wing pads present in females; 7) gill formula 3/4/4/3/1, gill V with ventral extension on dorsal lamella; 8) without strong setae on abdominal terga (Fig. 7).

Description. Nymph. Length of female (mm, not fully mature): body, 7.0; hind femur, 1.7; caudal filaments, 5.5 (cercus)-6.8 (terminal filament). General coloration yellowish brown, with gray markings (Figs 2, 6-7). Head yellowish with a blackish transverse band between eyes along the epicranial suture; occiput with small gray marks as in Fig. 6, posterior margin with a thin blackish line. Antennae whitish. Thorax: pronotum with large rounded anterolateral projection and pronounced constriction posteriorly, with gray markings as in figure (Fig. 6). Mesonotum with blunt anterolateral projections, and with gray markings as in Fig. 2; fore wingbuds black. Hind wing pad present in female. Thoracic sterna paler than terga, shaded with gray medially. Legs yellowish, shaded with gray on coxae, femora (except mediolongitudinal pale line), and base of tibia; legs almost completely covered by dark thick and short setae (Fig. 7), except for bare mediolongitudinal dorsal line on femora. 

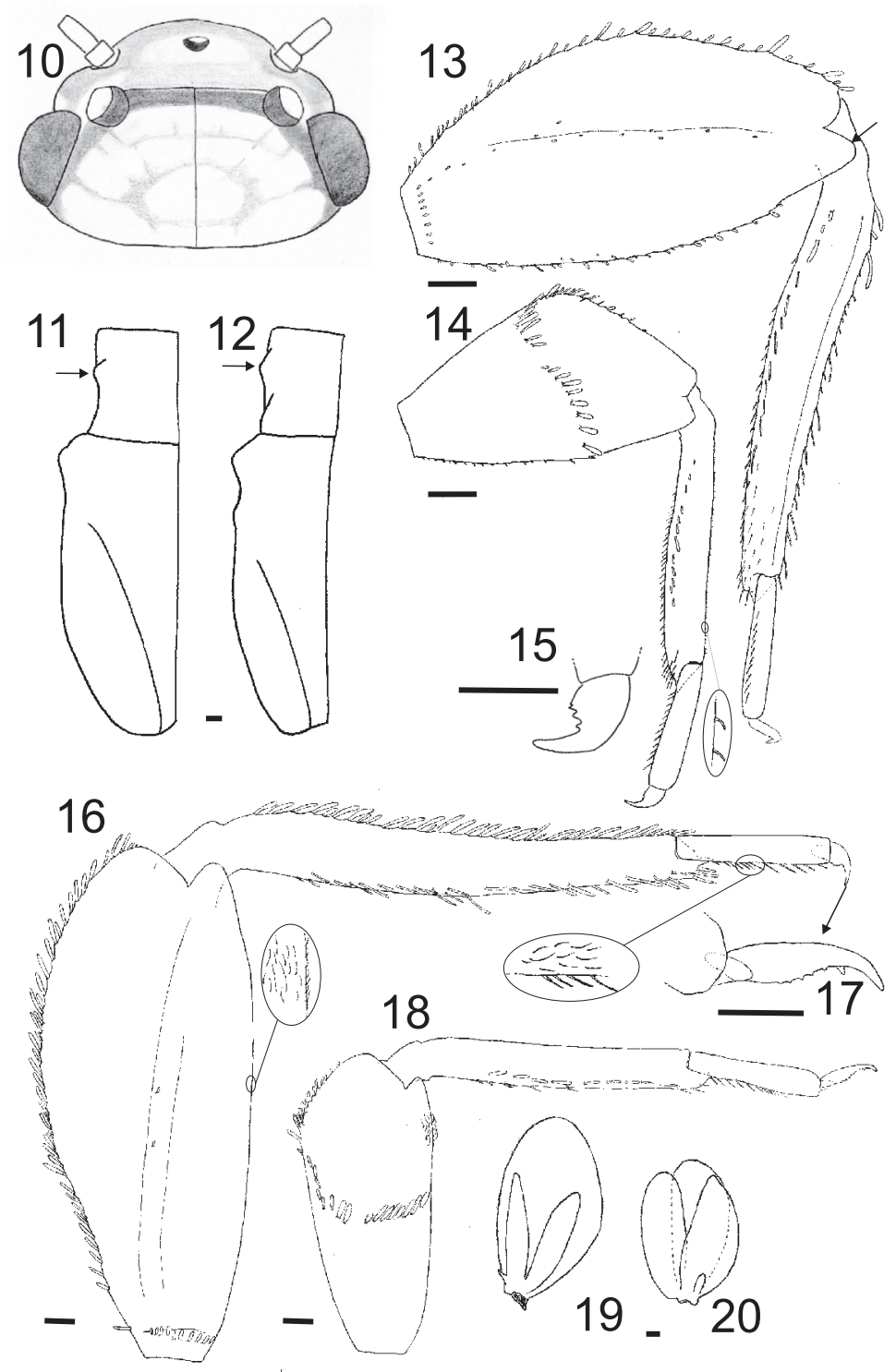

Figs 10-20. Leptohyphes andina sp. nov.: 10, dorsal color pattern of head; 11-12, outline (left side only) of pro- and mesonotum (arrows indicate triangular projection on pronotum); 13, hind leg; 14, foreleg; 15, fore tarsal claw. Leptohyphes calarca sp. nov.: 16, hind leg; 17, hind tarsal claw; 18, foreleg; 19, operculate gill, ventral; 20, gill III, ventral. Scale bars $=0.1 \mathrm{~mm}$.

Foreleg (Fig. 18): femur slender, becoming wider apically, ratio length/maximum width 2.3 ; transversal row at 0.4 from base to apex, with 25 stout spatulate spine-like setae; fore margin with spine-like setae, hind margin with spine-like setae (on elevated sockets) distally to transversal row; small inner projection on apex of femur. Tibia subequal in length to femur with spatulate setae along inner margin. Tarsus 0.4 the length of tibia with row of setae in inner margin; tarsal claw with $5+1$ denticles (Fig. 17). Middle and hind legs (Fig. 16) similar except for the size; hind femur becaming wider apically, ratio length/maximum width 2.4 , with double row of spine-like setae on fore margin, hind margin with 39 spinelike setae on elevated sockets; projections on inner apex of femur small. Tibia wide, 1.2 the length of femur, with dorsal ridge, inner and outer margin row of large spatulate setae (Fig. 16). Tarsus 0.3 the length of femur, inner margin with setae, tarsal claw as in foreleg. Abdomen. Terga brownish, shaded uniformly with gray; few spatulate setae present on lateral areas of segments III-VII. Lateral margins of segments III-VI expanded forming flanges; relatively short posterolateral spines on segments VII-IX. Abdominal sterna shaded slightly with gray. Sternum IX with distal V-shaped indentation (female). Gills: operculate gill on segment II whitish, shaded with brown on basal half, ventrally with curved "basal spine" and two lamellae (Fig. 19); other gills whitish (Fig. 20). Gill formula 3/4/4/3/1. Caudal filaments yellowish with few short and blunt brownish spines.

Adults. Unknown. The wing membrane is surely tinged with gray or black because of the pigments shown in the nymphal wing buds.

Etymology. Calarcá is the name of the municipality where the nymphs were collected; the name refers to the 
legendary Cacique Calarcá, from an ethnic group known as Pijaos who occupied the Colombian central Andean region. Distribution (Fig. 29). Colombia, Quindío (high Central Andes).

Discussion. The large size and pilose legs resembles L. quimbaya, but L. calarca is even larger and hair-like setae on the head, thorax and abdomen are lacking. Other important differences include the larger and rounded anterolateral projection on pronotum, the blackish wing buds and the presence of subapical submarginal denticle in tarsal claws of L. calarca.

Ecological notes. Known locality records of this species are from La Sonadora Natural Reserve, on the eastern slope of the Central Cordillera, Quindío (Calarcá and Córdoba municipalities). They were found between 2800 and 3100 $\mathrm{m}$. The region present $2000-4000 \mathrm{~mm}$ of annual rainfall and temperatures ranging $9-16^{\circ} \mathrm{C}$ (BAQUERo et al., 2010), with constant winds and fog. The area corresponds to Montane Humid Forest in HoLDRIDGE's (1987) classification. Streams are small, low-order reaches located in the high microbasin of La Sonadora and draining to the Verde river basin. They flow through a scarped terrain, with high slopes and falls of 3 to $15 \mathrm{~m}$ high, with well-preserved dense marginal vegetation cover. The streams presented a depth of 18-35 cm, channel with of $130-270 \mathrm{~cm}$, and velocity of $0.15-0.50 \mathrm{~m} / \mathrm{s}$. Bed substrate is muddy with high levels of leaves and other decomposing organic material, but sandy and stony substrate is present also in some creeks, but in a lower proportion.

\section{Leptohyphes quimbaya Molineri, Zúñiga \& Ramos sp. nov.}

(Figs 3, 8-9, 21-27)

LSIDurn:Isid:zoobank.org:act:7A14AC75-BF35-49799AF9-533481E4109F

Type material. Holotype $q$ mature nymph (parts on slide), from COLOMBIA, Risaralda, La Celia, La Esmeralda farm, San Camilo creek, Monos river basin, 0502'8.5’ N, 7559'46.7”W, 1648 m, microhábitat: cobble and gravel mixture, 11.II.2011, W. Cardona col. (MUSENUV). Paratypes: $1 \delta$ mature nymph, same data as holotype (IBN); 1 nearly mature $q$ nymph, the same information except Monos river-La Linda creek, 0500'40.5”N, 7600'53.7’'W, 1551 m, microhabitat: cobble and gravel, 8.II.2011 (MUSENUV); $1 \delta^{\Uparrow}$ immature nymph, the same information except La Pradera farm, La Reina creek, 0457’52.7’N, 7600'7’W, 1480 m, microhabitat: cobble and gravel, 15.II.2011(MUSENUV).

Additional material. Two $\delta$ and 29 immature nymphs from Risaralda, Santuario, Finca La Gaviota farm, La Gaviota creek, 0502’39.8’N, 7559’40.4’W, 1638 m, microhabitat: cobble and gravel, 12.II.2011, W. Cardona col. (2 in MUSENUV, 2 in IBN); 19 immature nymph from Risaralda, La Celia, San Camilo farm, San Camilo creek, 0502'12”N, 7559'34.9”W, 1779 m, microhabitat: stones, 10.II.2011, W. Cardona col. (MUSENUV); 49 immature nymphs, the same information except Verdum Regional Natural Park, Monos river, 0500'56.2”N, 7601'49.6”'W, 1846 m, microhabitat: cobble and gravel, 5.II.2011 (MUSENUV).

Diagnosis. 1) large, body covered by hair-like setae (Figs 3, 8, 9), with paired short and blunt tubercles on abdominal terga V-IX (Figs 26, 27); 2) femora wide, fore femur (Fig. 24) length/maximum width, 1.6 (mature nymphs) and 1.2 (immature nymphs), with mediolongitudinal row of spine-like setae distally to transverse row ("d.r." in Fig. 24); 3) fore and hind margin of femora with tiny spine-like setae (Figs 23, 24); 4) tarsal claws denticulation 2-3+0 (Fig. 25); 5) pronotum with triangular (but apically blunt) lateral projection (Fig. 8, 22); 6) hind wing pads present in females; 7) gill formula $3 / 7 / 7 / 5 / 2$, gill $\mathrm{V}$ without ventral extension on dorsal lamella.

Description. Mature nymph. Length of female (mm): body, 7.1-9.2; hind femur, 1.9-2.0; caudal filaments, 7.5. General coloration light brown, body and legs dorsally covered with whitish hair-like setae, venter glabrous. Head with black transverse band from eye to eye as in Fig. 21; occiput with finely marked gray net-pattern (Fig. 21). Thorax: nota brownish with gray markings. Pronotum subrectangular with small lateral subtriangular projection, and an oblique indentation near posterior margin ( $s p$ and oi in Fig. 22). Mesonotum with anterolateral corners not projected (Fig. 22). Hind wing pads present in female. Legs yellowish shaded dorsally with gray except mediolongitudinal narrow band on all femora (Fig. 9). Foreleg (Fig. 24): femur wide, ratio length/maximum width 1.6; transversal row of setae at $1 / 2$ from base; fore margin with setae, hind margin with setae (on elevated sockets); apex of femur projected on inner and outer margins (Fig. 24). Tibia subequal in length to femur with row of setae on inner margin; tarsus 0.4 the length of tibia with row of setae on inner margin; tarsal claw with two to three marginal denticles and none subapical submarginal denticle (Fig. 25). Middle and hind legs (Fig. 23) similar, except hind leg larger; hind femur ratio length / maximum width $=2$; fore margin with 3-4 rows of short blunt setae, hind margin with 70 stout spine-like setae on elevated sockets (the sockets and the spines are very small), dorsal surface with many small scattered spine-like setae; distal projections on apex of femur more pronounced than foreleg. Tibia 1.1 the length of femur, with dorsal ridge, inner and outer margins with short weak spine-like setae. Tarsus 0.3 the length of tibia, inner margin with setae, tarsal claw as in foreleg. Abdomen (Figs 26,27 ) brownish shaded widely with gray, ventrally paler. Terga (Figs 9, 26) covered by whitish hair-like setae, mainly along hind margin; short blunt spine-like setae scattered on terga, mainly on submedian tubercles; segments III-VI with lateral flanges, small and poorly developed posterolateral projections on VII-IX; sternum IX with distomedial notch. Gills: operculate gill completely shaded with gray, except margins; other gills whitish shaded slightly with gray. Gill formula 3/7/7/5/2; gill V without ventral extension. Caudal filaments with scattered setae, and whorl of spines at joinings.

Variation: early instars of L. quimbaya only show groups of small setae on the area where abdominal tubercles 

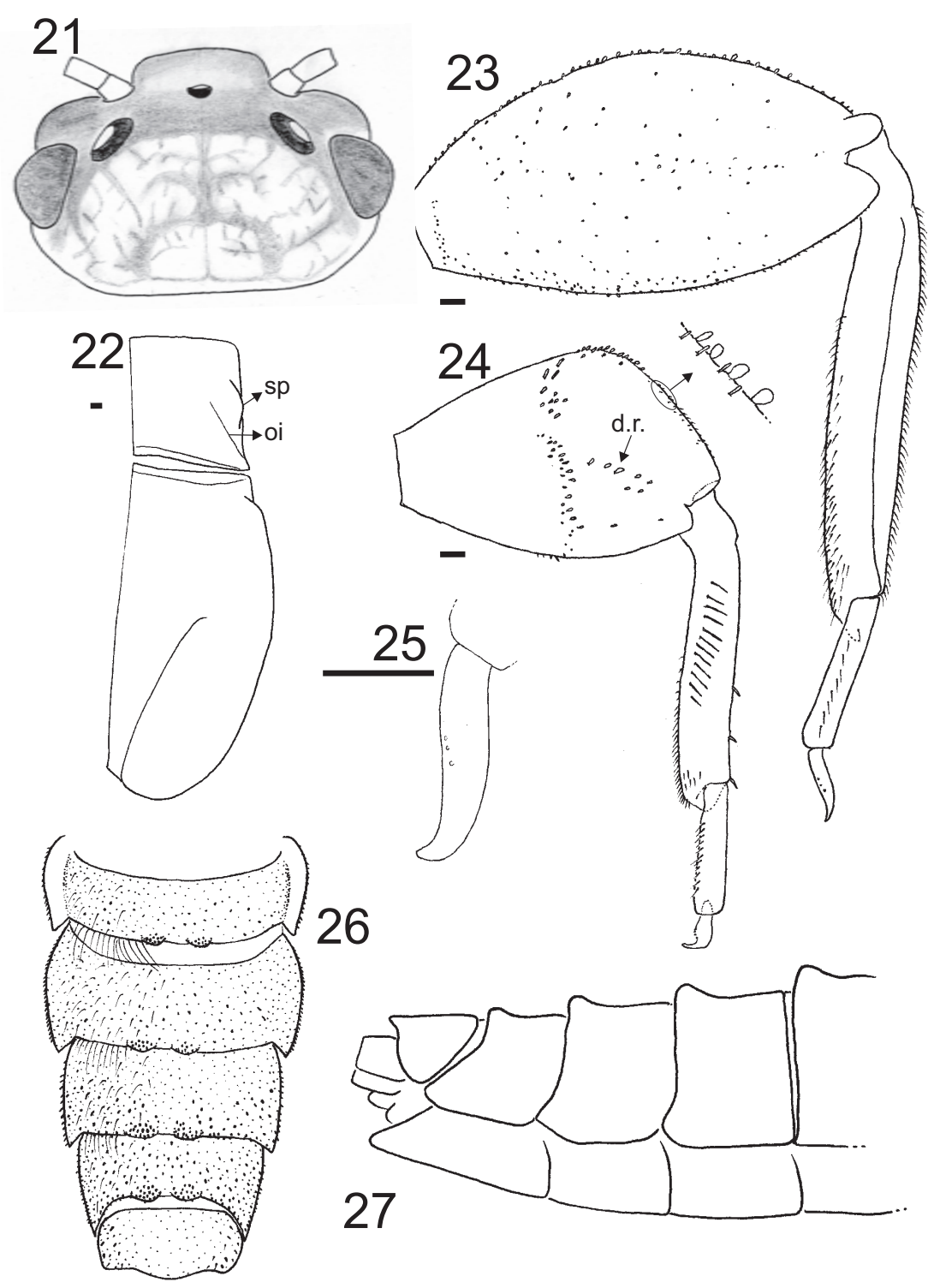

Figs 21-27. Leptohyphes quimbaya sp. nov.: 21, dorsal color pattern of head; 22, outline (right side only) of pro- and mesonotum; 23, hind leg; 24, foreleg; 25, fore tarsal claw; 26, abdomen, dorsal (long setae omitted on right side); 27 , abdomen, lateral (outline, setation omitted). Scale bars = $0.1 \mathrm{~mm}$.

will develop, and their almost circular forefemur does not present the mediolongitudinal row of spine-like setae distally. Adults. Unknown.

Etymology. Quimbaya refers to an ethnic group that inhabited the valley of the Cauca river, between the Central and Western Cordilleras in Colombia, now the departments of Caldas, Quindío and Risaralda.

Distribution (Fig. 30). Colombian Western Cordillera, Risaralda department, middle basin of Cauca River.

Discussion. The uncommon large body size together with the many tiny femoral spine-like setae, the setose body, very wide femora and paired abdominal tubercles readily distinguish this species from any other in the genus. Leptohyphes quimbaya is similar to L. pilosus Allen \& Brusca, 1973, mainly in the body pilosity, but the last species presents fewer and larger spine-like setae on slender femora. Abdominal tubercles are present in few other species of the genus, but only in L. nebulosus Nascimento et al., 2014 they are paired, nevertheless the later presents spine-like setae on very elevated sockets on femora, and is restricted to Brazilian coastal Atlantic forest (NAScimENTo et al., 2014). Ecological notes. The species was collected in several creeks on the eastern slopes of the Western Cordillera in Colombia (Risaralda department). The landscape spans elevations from 1300 to $2000 \mathrm{~m}$, where sun-grown coffee is dominant (WCS, 2013) and corresponds to the transition zone between the Lower Montane Wet Forest and Premontane Moist Forest (Espinal 1977). Mean annual rainfall is 2500 $\mathrm{mm}$ and mean annual temperature is $18^{\circ} \mathrm{C}$. The landscape is a mosaic of vegetation types dominated by patches of native vegetation that differ in size (located at the top of the mountains and in glens), sun-grown coffee plantations, annual crops, stover and pasture (WCS, 2013). The Verdum Municipal Natural Park in this study area is located in the 

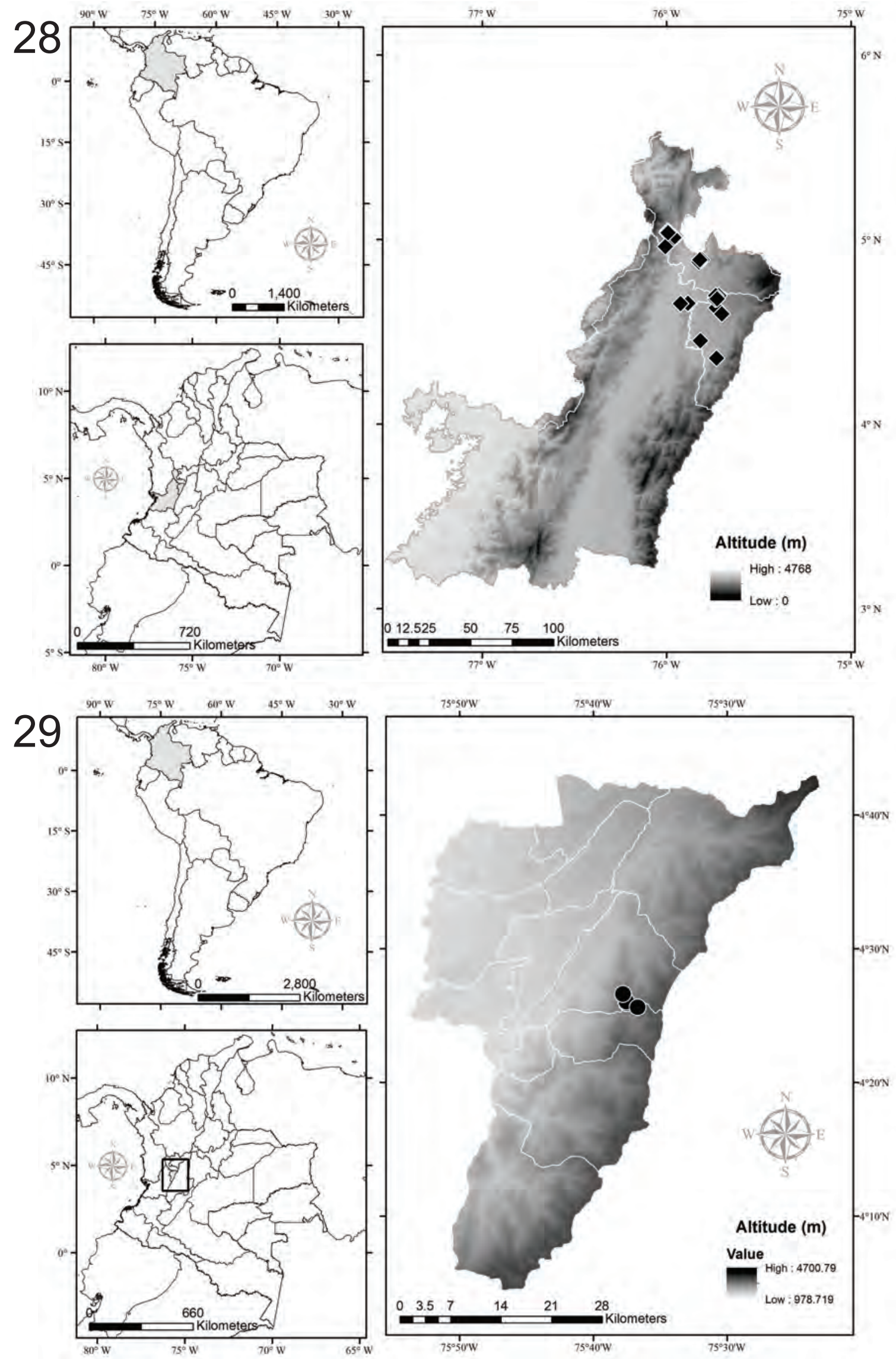

Figs 28-29. Distribution maps: 28, Leptohyphes andina sp. nov.; 29, L. calarca sp. nov. 


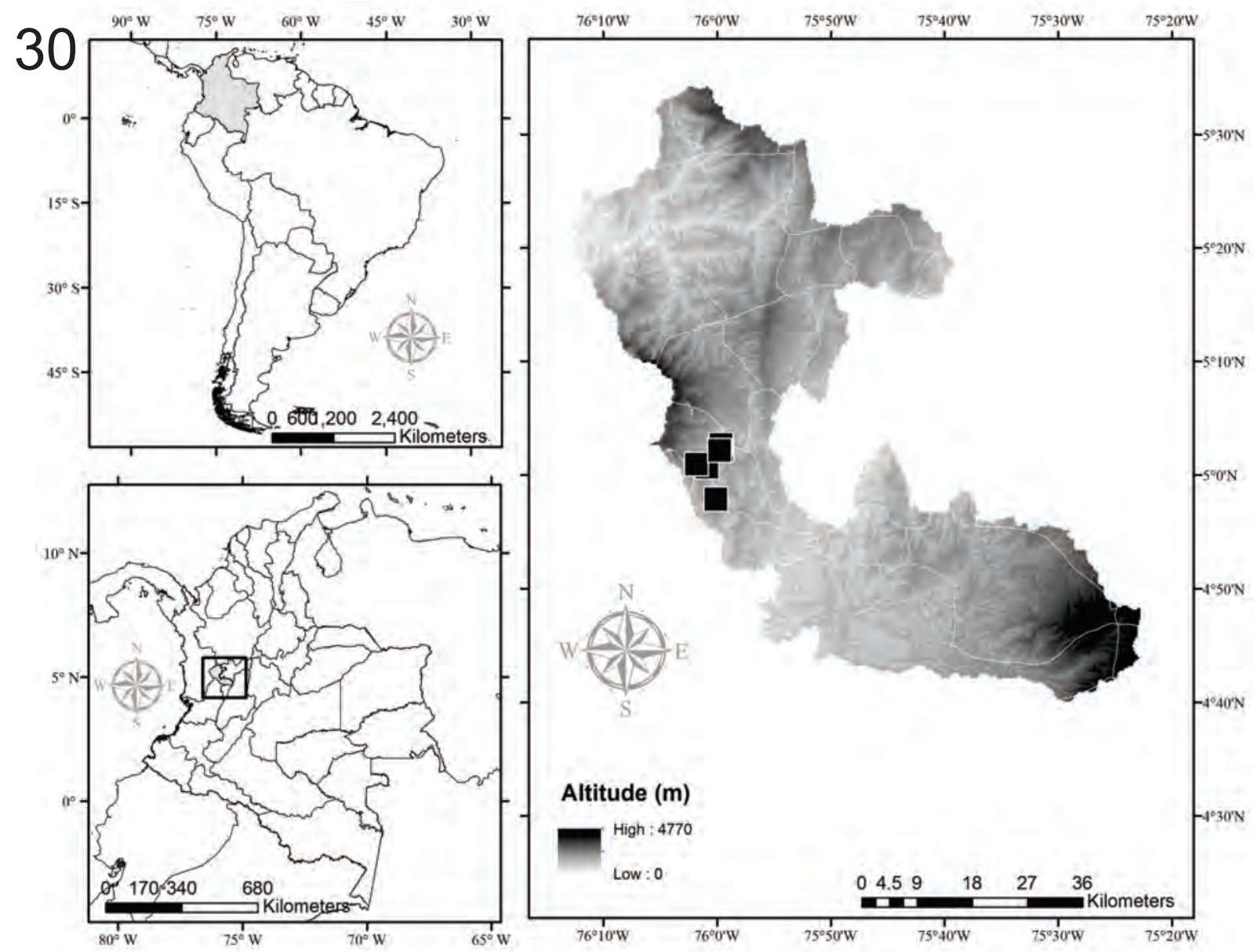

Fig. 30. Distribution map of Leptohyphes quimbaya sp. nov.

buffer zone of the Tatamá National Natural Park and it is important in environmental terms as a reservoir of Andean forest.

Acknowledgments. We are indebted to Universidad del ValleLaboratorio de Investigaciones Entomológicas for logistic support, and to Laboratorio de Imágenes (Programa de Posgrado en Biología), specially to Felipe Ortega for photographic records of the studied material. Also to Centro para la Investigación en Sistemas Sostenibles de Producción Agropecuario-CIPAV, particularly Julián Chará who kindly offered specimens and information. Material collection in La Vieja and Otun rivers basin (departaments of Valle del Cauca, Quindío and Risaralda) was co-financed by the Departamento Administrativo de Ciencia, Tecnología e Innovación (COLCIENCIAS), Colombia, Global Environmental Facility (GEF)-Banco Mundial, Food and Agriculture Organization of the United Nations (FAO), Livestock Environmental and Development (LEAD), Corporación Autónoma Regional del Valle del Cauca (CVC) and Centro de Investigaciones y Estudios en Biodiversidad y Recursos Genéticos (CIEBREG). We thank also to Wildlife Conservation Society (WCS)-Programa Colombia, material collection in La Celia and Santuario localities (Risaralda department) was cofinanced by this institution. Alejandro Villarreal-Grisales (Universidad del Quindío) offered specimens and information from La Sonadora Natural Reserve (Quindio-Calarcá). We also are grateful to Julián Chará, Ana Marcela Chará Serna, Gloria Pedraza, Adriana Giraldo and Denise Hincapié for their help in collecting field. Finally we are indebted with many land-owners that permitted access to creeks located inside private areas and Cristian Román for the elaboration of maps.

\section{REFERENCES}

Baquero, J. C.; Duque, J. M. \& Gómez, G. 2010. Composición florística en La Sonadora, Calarcá, Quindío. Armenia, Universidad del Quindio, Colombia. 90p.

Baumgardner, D. E. \& McCAFferty, W. P. 2010. Revision of the genus Leptohyphes Eaton (Ephemeroptera: Leptohyphidae) in North and Central America. Zootaxa 2360:1-33.

Chará, J. D.; ZúÑIGa, M. C.; Giraldo, L. P.; Pedraza, G.; Astudillo, M.; Ramírez, L. \& Posso, C. E. 2009. Diversidad y abundancia de macroinvertebrados acuáticos en quebradas de la cuenca del río La Vieja, Colombia. In: Centro de Investigaciones y Estudios en Biodiversidad y Recursos Genéticos-CIEBREG. eds. Valoración de la Biodiversidad en la Ecorregión del eje cafetero. Pereira, Colombia, p. 129-142.

Chará-Serna, A. M.; Chará, J. D.; ZúÑIga, M. C.; Pedraza, G. \& Giraldo, L. P. 2010. Clasificación trófica de insectos acuáticos en ocho quebradas protegidas de la ecorregión cafetera colombiana. Universitas Scientiarum 15:27-36.

Chará-Serna, A. M.; Chará, J. D.; ZúÑiga, M. C.; Pearson, R. G. \& Boyero, L. 2012. Diets of leaf litter-associated invertebrates in three tropical streams. International Journal of Limnology 48:139-144.

Dias, L.; Bacca, T.; Navarro, L.; Acevedo, F.; Benavides, P. \& FiuzaFERREIRA, P. S. 2011. Association of nymphs and adults of Ephemeroptera (Insecta) using the amplified fragment length polymorphism (AFLP) technique. International Journal of Limnology 47:151-157.

Domínguez, E.; Molineri, C.; Pescador, M.; Hubbard, M. D. \& Nieto, C. 2006. Ephemeroptera of South America. Aquatic Biodiversity in Latin America (ABLA), Vol. 2, Sofia-Moscow, Pensoft. 644p. 
EsPINAL, S. 1977. Zonas de vida y formaciones vegetales de Colombia, Instituto Geográfico Agustín Codazzi-IGAG Vol. XIII, No 11. Bogotá, Colombia. 337p.

Guzmán-Soto, C. J. \& Tamarís-Turizo, C. E. 2014. Hábitos alimentarios de individuos inmaduros de Ephemeroptera, Plecoptera y Trichoptera en la parte media de un río tropical de montaña. Revista de Biología Tropical 62(Supp.2):169-178.

Hoffmann, C.; Sartori, M. \& Thomas, A. 1999. Les Éphéméroptères (Ephemeroptera) de la Guadeloupe (petites Antilles françaises). Mémoires de la Société Vaudoise des Sciences Naturelles 20:1-96.

Holdridge, L. R. 1987. Ecología basada en zonas de vida (Colección libros y materiales educativos No. 83). 3ed. San José de Costa Rica, Instituto Interamericano de Cooperación para la Agricultura. 216p.

Molineri, C. 2003. Revision of the South American species of Leptohyphes Eaton (Ephemeroptera: Leptohyphidae) with a key to the nymphs. Studies on Neotropical Fauna and Environment 38(1):47-70.

Molineri, C. 2010. Las especies de Leptohyphidae (Ephemeroptera) de las yungas de Argentina y Bolivia: diagnósis, distribución y claves. Revista de la Sociedad Entomológica Argentina 69:233-252.

Molineri, C. \& Zúñiga, M. C. 2006. New species of Leptophyphidae (Insecta: Ephemeroptera) from Colombia with evidence of reproductive time segregation. Studies on Neotropical Fauna and Environment 41:139-151.

Nascimento, J. M. C.; Molineri, C. \& Salles, F. F. 2014. Redescription of Leptohyphes cornutus Allen, 1967 (Ephemeroptera: Leptohyphidae) and description of three related new species. Zootaxa 3893:397-415.

Отт, R. W.1981. Water pollution indices. In: Environmental Indices. Theory and Practice. Michigan, Ann Arbor Science Publishers Inc., p. 203-213.

Reynaga, M. C. \& dos Santos, D. A. 2013. Contrasting taxonomical and functional responses of stream invertebrates across space and time in a Neotropical basin. Fundamental and Applied Limnology 183(2):121-133.
Tomanova, S.; Goitia, E. \& Helešic, J. 2006. Trophic levels and functional feeding groups of macroinvertebrates in neotropical streams. Hydrobiologia 556:251-264.

WCS - Wildlife Conservation Society Colombia. 2013. Conociendo la biodiversidad de nuestro paisaje rural cafetero, La Celia, Balboa y Santuario-Risaralda. Santiago de Cali, Wildlife Conservation Society Colombia-McArthur Foundation. Available at <http://colombia.wcs. org/Sobre-nosotros/Publicaciones.aspx>. Accessed on 11 January 2016.

Zúñiga de Cardozo, M. C.; Rojas de Hernández, A. M. \& Mosquera DE Aguilera, S. 1997. Biological aspects of Ephemeroptera in rivers of southwestern Colombia (South America). In: LANDOLT, P. \& SARTORI, M. eds. Ephemeroptera \& Plecoptera: Biology-Ecolgy-Systematics. Fribourg, MTL, p. 261-268.

ZúÑiga, M. C.; Molineri, C. \& Domínguez, E. 2004. El orden Ephemeroptera (Insecta) en Colombia. In: Fernández, F.; Andrade, G. \& Amat, G. eds. Insectos de Colombia. Vol. 3. Santafé de Bogotá, Universidad Nacional de Colombia. Unibiblos, p. 17-42.

ZúÑIGA, M. C. \& CARDONA, W. 2009. Bioindicadores de calidad de agua y caudal ambiental. In: CANTERA-Kintz, J. R.; CARVAJAL-ESCOBAR, Y. \& Castro-Heredia, L. M. eds. Caudal ambiental: conceptos, experiencias y desafíos. Santiago de Cali, Programa Editorial Universidad del Valle, Colección Libros de Investigación, p. 167-198.

ZúÑiga, M. C.; Chará, J. D.; Giraldo, L. P.; Chará-Serna, A. M. \& PedrazA, G. 2013. Composición de la comunidad de macroinvertebrados acuáticos en pequeñas quebradas de la región andina colombiana, con énfasis en la entomofauna. Dugesiana 20:263-277.

Zúñiga, M. C.; Cardona, W.; Molineri, C.; Mendivil, J.; Cultid, C.; Chará, A. M. \& Giraldo, A. 2014. Entomofauna acuática del Parque Nacional Natural Gorgona (Colombia), con énfasis en Ephemeroptera y Plecoptera. Revista de Biología Tropical 62(Suppl.1):221-241. 


\section{Erratum}

DOI: $10.1590 / 1678-4766 e 2016024$ erratum

Erratum of article

Molineri, Carlos, Zúñiga, María del Carmen, Ramos, Blanca C., Giraldo, Lina P., \& Cardona, William. (2016). Three new species of Leptohyphes Eaton (Ephemeroptera: Leptohyphidae) from Colombia. Iheringia, Série Zoologia 106 : e2016024. Available from: <http://www.scielo.br/scielo.php?

script=sci_arttext\&pid=S0073-47212016000100224\&lng=en\&nrm=i so $>$. Epub Oct 20, 2016. ISSN 0073-4721. http://dx.doi.org/10.1590/1678-4766e2016024.

Page 1, address \#1, line 2: "Ciudad Universitaria, Horco Molle (4107)" instead of "M. Lillo 205 (4000)";

Page 1, second paragraph, last line: "Peru" instead of "PerU";

Page 2, first column, line 5: “...on the second abdominal...” instead of “...on the first abdominal...”;

Page 2, first column, line 7: “...the third abdominal...” instead of “...the second abdominal...”;

Page 2, second column, line 28: “...1638 m” instead of “...638 m”;

Page 4, second column, line 10 (last line): “...with three to four marginal...” instead of “...with four marginal...”;

Page 5, first column, line 28: “... and Valle del Cauca, from 750 to 1648 asl.” instead of “...and North of Valle del Cauca, from 750 to 1648 masl.";

Page 7, “...organic material, sandy and stony..." instead of “...organic material, but sandy and stony...”;

Page 10, Acknowledgments, line 15: “...Programa Colombia, and Mc Arthur Foundation, material...” instead of "Programa Colombia, material...";

Page 10, Acknowledgments, line 17: “...cofinanced by these institutions.” instead of "...cofinanced by this institution.". 